\title{
Front Matter: Volume 9940
}

, "Front Matter: Volume 9940," Proc. SPIE 9940, Liquid Crystals XX, 994001 (22 November 2016); doi: 10.1117/12.2262206

SPIE Event: SPIE Organic Photonics + Electronics, 2016, San Diego, California, SPIE. United States 


\section{PROCEEDINGS OF SPIE}

\section{Liquid Crystals XX}

\section{Iam Choon Khoo}

Editor

\section{8-30 August 2016}

San Diego, California, United States

Sponsored and Published by

SPIE 
The papers in this volume were part of the technical conference cited on the cover and title page. Papers were selected and subject to review by the editors and conference program committee. Some conference presentations may not be available for publication. Additional papers and presentation recordings may be available online in the SPIE Digital Library at SPIEDigitallibrary.org.

The papers reflect the work and thoughts of the authors and are published herein as submitted. The publisher is not responsible for the validity of the information or for any outcomes resulting from reliance thereon.

Please use the following format to cite material from these proceedings:

Author(s), "Title of Paper," in Liquid Crystals XX, edited by lam Choon Khoo, Proceedings of SPIE Vol. 9940 (SPIE, Bellingham, WA, 2016) Six-digit article CID Number.

ISSN: 0277-786X

ISSN: 1996-786X (electronic)

ISBN: 9781510602717

ISBN: 9781510602724 (electronic)

Published by

SPIE

P.O. Box 10, Bellingham, Washington 98227-0010 USA

Telephone +1 3606763290 (Pacific Time) · Fax +1 3606471445

SPIE.org

Copyright (C) 2016, Society of Photo-Optical Instrumentation Engineers.

Copying of material in this book for internal or personal use, or for the internal or personal use of specific clients, beyond the fair use provisions granted by the U.S. Copyright Law is authorized by SPIE subject to payment of copying fees. The Transactional Reporting Service base fee for this volume is $\$ 18.00$ per article (or portion thereof), which should be paid directly to the Copyright Clearance Center (CCC), 222 Rosewood Drive, Danvers, MA 01923. Payment may also be made electronically through CCC Online at copyright.com. Other copying for republication, resale, advertising or promotion, or any form of systematic or multiple reproduction of any material in this book is prohibited except with permission in writing from the publisher. The CCC fee code is 0277-786X/16/\$18.00.

Printed in the United States of America.

Publication of record for individual papers is online in the SPIE Digital Library.

\section{SPIE. DIGITAL \\ SPIEDigitallibrary.org}

Paper Numbering: Proceedings of SPIE follow an e-First publication model. A unique citation identifier (CID) number is assigned to each article at the time of publication. Utilization of CIDs allows articles to be fully citable as soon as they are published online, and connects the same identifier to all online and print versions of the publication. SPIE uses a six-digit CID article numbering system structured as follows:

- The first four digits correspond to the SPIE volume number.

- The last two digits indicate publication order within the volume using a Base 36 numbering system employing both numerals and letters. These two-number sets start with $00,01,02,03,04,05$, $06,07,08,09,0 A, 0 B \ldots$. OZ, followed by 10-1Z, 20-2Z, etc. The CID Number appears on each page of the manuscript. 


\title{
Contents
}

\author{
$\checkmark$ Authors \\ vii Conference Committee
}

\section{LIQUID CRYSTAL PHOTONICS}

994003 Array of liquid crystal polymer-based Fabry-Perot resonators for image selection by polarization (Invited Paper) [9940-2]

994004 Effect of UV absorption anisotropy on hybrid aligned polymer stabilized liquid crystal cell (Invited Paper) [9940-3]

\section{OPTICAL SWITCHING, HOLOGRAPHY, AND ALIGNMENT}

994006 Light-induced effects in liquid crystals: recent developments (Keynote Paper) [9940-5]

994008 Pretilt angle of liquid crystals generated by polyimide photoalignment layers treated with vapor of primary and tertiary alkylamines (Invited Paper) [9940-7]

994009 Elimination of image flicker in a fringe-field switching liquid crystal cell (Invited Paper) [9940-8]

\section{POLARIZED LUMINESCENCE AND LIGHT-INDUCED EFFECTS}

9940 OA Helicity, assembly, and circularly polarised luminesence of chiral AIEgens (Keynote Paper) [9940-9]

9940 OB Direct induction of molecular alignment in liquid crystal polymer network film by photopolymerization (Invited Paper) [9940-10]

9940 OC Theory and computer simulation of photo induced deformations in liquid crystal azobenzene polymers (Invited Paper) [9940-11]

\section{MOLECULAR ASSEMBLY AND OPTICAL DEVICES}

9940 0G All-optical phase shifter with photovoltaic liquid crystal cell (Invited Paper) [9940-15]

BIO-SENSING AND ELECTRO-OPTICAL DEVICES

9940 OK Chiral liquid crystals as biosensing platforms (Invited Paper) [9940-19] 
9940 ON Liquid crystals for optical modulation and sensing applications (Invited Paper) [9940-22]

MOLECULAR DYNAMICS, PHASE TRANSITION, AND DEFECT STRUCTURES

9940 OU Mesomorphic glass nanocomposites made of metal alkanoates and nanoparticles as emerging nonlinear-optical materials (Invited Paper) [9940-29]

9940 OV Unveiling details of defect structures in chiral and achiral nematic droplets by improving simulations of optical images (Invited Paper) [9940-30]

9940 0W Direct evidence of the molecular interaction propagation in the phase transition of liquid crystals (Invited Paper) [9940-31]

9940 0X A non-mechanical zoom lens fabricated from liquid crystal reactive mesogens [9940-32]

HELICAL- AND BLUE-PHASE, PLASMONIC, AND THZ

$99400 Z$ Diffractive devices based on blue phase liquid crystals (Invited Paper) [9940-34]

994010 Effect of dielectric permittivity on the performance of polymer dispersed liquid crystal (PDLC) electrolyte dye-sensitized solar cells (DSSCs) [9940-35]

994013 Longitudinal stratified liquid crystal structures to enable practical spatial light modulators in the terahertz regime [9940-38]

\section{NEXT/NEW GENERATION LC PHOTONICS}

994019 Tuning surface plasmons in graphene ribbons with liquid crystal layer (Invited Paper) [9940-44]

9940 1B Fabrication of micro- and nanometre-scale polymer structures in liquid crystal devices for next generation photonics applications [9940-46]

\section{POSTER SESSION}

9940 1E Field induced UV-alignment method for a zero pre-tilt liquid crystal cell [9940-49]

994011 Thermal modulation of selective transmittance spectra by combination of cholesteric liquid crystal cells [9940-53]

$99401 \mathrm{~J}$ Resonant mode at the band edge [9940-54] 


\section{Authors}

Numbers in the index correspond to the last two digits of the six-digit citation identifier (CID) article numbering system used in Proceedings of SPIE. The first four digits reflect the volume number. Base 36 numbering is employed for the last two digits and indicates the order of articles within the volume. Numbers start with 00, 01, 02, 03, 04, 05, 06, 07, 08, 09, 0A, 0B...0Z, followed by 10-1Z, 20-2Z, etc.

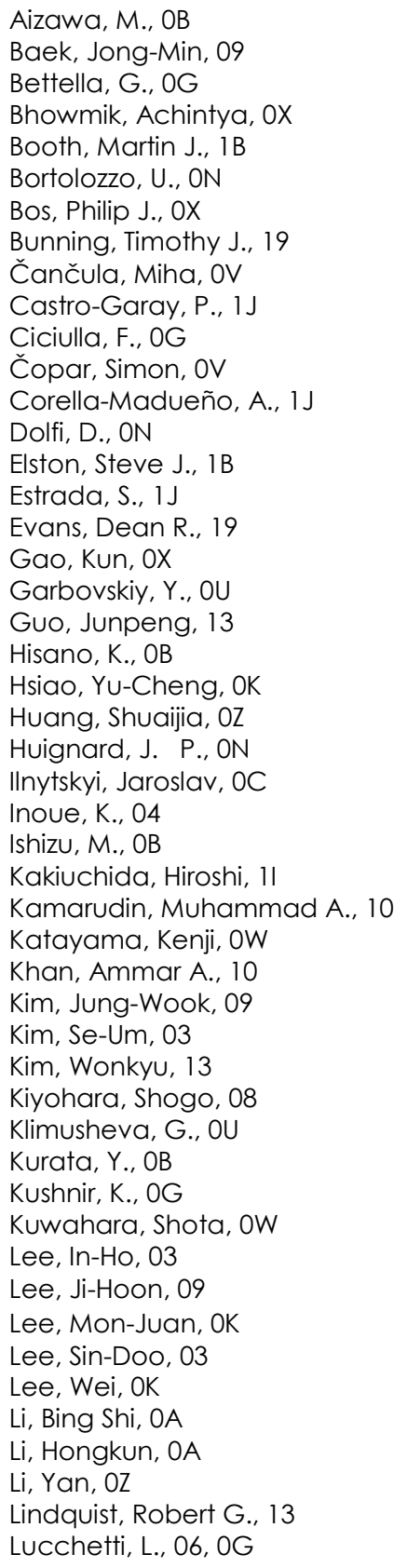

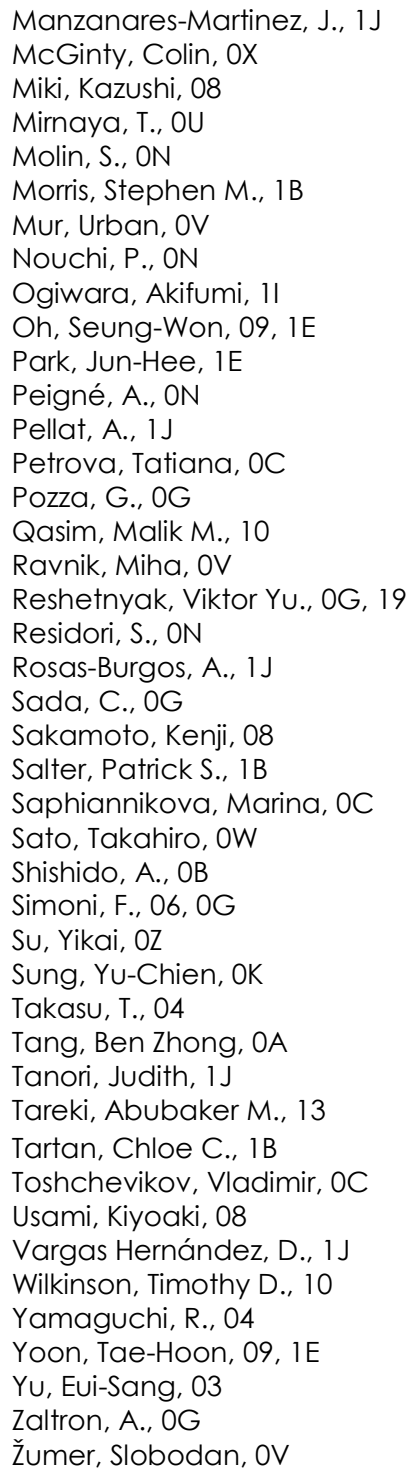


Proc. of SPIE Vol. $9940994001-6$

Downloaded From: https://www.spiedigitallibrary.org/conference-proceedings-of-spie on 26 Apr 2023 Terms of Use: https://www.spiedigitallibrary.org/terms-of-use 


\section{Conference Committee}

Symposium Chairs

Zakya H. Kafafi, Lehigh University (United States)

Luisa Torsi, Università degli Studi di Bari (Italy)

Conference Chair

Iam Choon Khoo, The Pennsylvania State University (United States)

Conference Program Committee

Timothy J. Bunning, Air Force Research Laboratory (United States)

Shaw-Horng Chen, University of Rochester (United States)

Neil Collings, Two Trees Photonics Ltd. (United Kingdom)

Jean-Pierre Huignard, Jphopto (France)

Tomiki Ikeda, Chuo University (Japan)

Malgosia Kaczmarek, University of Southampton (United Kingdom)

Oleg D. Lavrentovich, Kent State University (United States)

Sin-Doo Lee, Seoul National University (Korea, Republic of)

Tsung-Hsien Lin, National Sun Yat-Sen University (Taiwan)

Francesco Simoni, Università Politecnica delle Marche (Italy)

Nelson V. Tabiryan, BEAM Company (United States)

David M. Walba, University of Colorado at Boulder (United States)

Shin-Tson Wu, CREOL, The College of Optics and Photonics, University of Central Florida (United States)

Session Chairs

1 Liquid Crystal Photonics

Iam Choon Khoo, The Pennsylvania State University (United States)

2 Optical Switching, Holography, and Alignment

Timothy J. Bunning, Air Force Research Laboratory (United States)

3 Polarized Luminescence and Light-induced Effects

Francesco Simoni, Università Politecnica delle Marche (Italy)

4 Molecular Assembly and Optical Devices

David Walba, University of Colorado Boulder (United States)

5 Bio-sensing and Electro-optical Devices

Oleg D. Lavrentovich, Kent State University (United States) 
6 3D Display and Advanced Photonics Devices

Tsung-Hsien Lin, National Sun Yat-Sen University (Taiwan)

7 Molecular Dynamics, Phase Transition, and Defect Structures

Sin-Doo Lee, Seoul National University (Korea, Republic of)

8 Helical- and Blue-Phase, Plasmonic, and $\mathrm{THz}$

Nelson V. Tabiryan, BEAM Engineering For Advanced Measurements Company (United States)

9 Novel LC Materials and Optical Devices

Nelson V. Tabiryan, BEAM Engineering For Advanced Measurements Company (United States)

10 Next/New Generation LC Photonics

Iam Choon Khoo, The Pennsylvania State University (United States) 